\title{
Biofilm formation by Staphylococcus epidermidis on nitrogen ion implanted CoCrMo alloy material
}

\author{
Orhan Öztürk, ${ }^{1}$ Mert Sudagidan, ${ }^{2}$ Uğur Türkan ${ }^{3}$ \\ ${ }^{1}$ Department of Physics, Izmir Institute of Technology, Urla, Izmir 35430, Turkey \\ ${ }^{2}$ Department of Biology, Izmir Institute of Technology, Urla, Izmir 35430, Turkey \\ ${ }^{3}$ Materials Science and Engineering Program, Izmir Institute of Technology, Urla, Izmir 35430, Turkey
}

Received 14 March 2006; revised 15 May 2006; accepted 8 August 2006

Published online 22 December 2006 in Wiley InterScience (www.interscience.wiley.com). DOI: 10.1002/jbm.a.31037

\begin{abstract}
Staphylococcus epidermidis is the primary cause of medical device-related infections due to its adhesion and biofilm forming abilities on biomaterial surfaces. For this reason development of new materials and surfaces to prevent bacterial adhesion is inevitable. In this study, the adhesion of biofilm forming S. epidermidis strain YT-169a on nitrogen $(\mathrm{N})$ ion implanted as well as on as-polished CoCrMo alloy materials were investigated. A medical grade CoCrMo alloy was ion implanted with $60 \mathrm{keV} \mathrm{N}$ ions to a high dose of $1.9 \times 10^{18}$ ions $/ \mathrm{cm}^{2}$ at substrate temperatures of 200 and $400^{\circ} \mathrm{C}$. The near-surface implanted layer crystal structures, implanted layer thicknesses, and roughnesses were characterized by XRD, SEM and AFM. The number of adherent bacteria on the surfaces of $\mathrm{N}$ implanted
\end{abstract}

specimens was found to be $191 \times 10^{6} \mathrm{CFU} / \mathrm{cm}^{2}$ for the $200^{\circ} \mathrm{C}$ and $70 \times 10^{6} \mathrm{CFU} / \mathrm{cm}^{2}$ for the $400^{\circ} \mathrm{C}$ specimens compared to the as-polished specimen $\left(3 \times 10^{6} \mathrm{CFU} / \mathrm{cm}^{2}\right)$. The adhesion test results showed that $S$. epidermidis strain YT169 a adhere much more efficiently to the $\mathrm{N}$ implanted surfaces than to the as-polished CoCrMo alloy surface. This was attributed mainly to the rougher surfaces associated with the $\mathrm{N}$ implanted specimens in comparison with the relatively smooth surface of the as-polished specimen. (C) 2006 Wiley Periodicals, Inc. J Biomed Mater Res 81A: 663-668, 2007

Key words: CoCrMo alloy; nitrogen ion implantation; biofilm formation; X-ray diffraction; atomic force microscopy

\section{INTRODUCTION}

In recent years, the skin commensal Staphylococcus epidermidis have been recognized as an important medical pathogen in biomaterial-related infections. ${ }^{1}$ The pathogenesis of S. epidermidis is associated with the biofilm forming abilities on biomaterial surfaces. Biofilm formation occurs in a two-step process. First, the bacteria rapidly adhere to the biomaterial surface reversibly by means of physicochemical interactions (van der Waals attraction forces, gravitational forces, the effect of electrostatic charge, hydrophobic interactions, ionic and dipole interactions). ${ }^{2}$ Second, the bacteria proliferate and accumulate to form multilayered cell clusters on the surface by molecular and cellular interactions between cell surface structures (e.g. slime) and material. ${ }^{2}$ Biofilm makes these embedded bacteria less accessible to the human defense system and

\footnotetext{
Correspondence to: O. Öztürk; e-mail: orhanozturk@iyte. edu.tr

Contract grant sponsor: Izmir Institute of Technology;
} contract grant numbers: 2003 IYTE 14, 2003 IYTE 01. decreases susceptibility against antibiotics. ${ }^{3}$ In other words, multiple resistance to antibiotics was more frequent among slime producing $S$. epidermidis strains. ${ }^{4}$ Metallic biomaterials especially placed in deep parts of the body with biofilm on their surface serve as an infection source and eventual removal of this material may be necessary.

Efforts to prevent bacterial adhesion and biofilm formation of biomaterials have mainly focused on the modification of their surfaces by coatings and surface modification techniques. Ion beam techniques can be used to reduce bacterial adhesion to the biomaterial surfaces. Previous studies report inhibition of bacterial adhesion and biofilm formation on metallic or polymer implants in vitro by coating and ion implanting surfaces of these materials with silver. ${ }^{5,6}$

Nitrogen $(\mathrm{N})$ ion implantation can be an efficient surface treatment technique to form protective layers on the surface of CoCrMo alloy and to induce new surface properties without affecting bulk properties as only a small thickness of the material is involved. It is generally accepted that $\mathrm{N}$ ion implantation is an excellent method to enhance wear and corrosion resistances of a wide range of materials. ${ }^{7}$ Several researchers have used ion beam applications in the 
medical area, ${ }^{8,9}$ such as for orthopedic prostheses that require high wear resistance and excellent corrosion properties as well as biocompatibility.

In the present study, surface modification by $\mathrm{N}$ ion implantation is explored as a possible means of inhibiting bacterial adhesion to CoCrMo alloys. In particular, the adhesion of biofilm forming S. epidermidis strain YT-169a onto the nitrogen implanted surfaces will be investigated and compared with untreated (polished) CoCrMo material surface. Our study combines the use of X-ray diffraction techniques $(\theta / 2 \theta$ XRD and GIXRD), cross-sectional scanning electron microscopy (SEM), and atomic force microscopy (AFM). Bacterial adhesion tests using $S$. epidermidis have been performed to evaluate the efficiency of $\mathrm{N}$ implanted surfaces to prevent and/or reduce bacterial adhesion and biofilm formation.

\section{METHODS}

\section{Materials}

Medical grade CoCrMo alloy (ISO 5832-12) with a base chemical composition of $26 \% \mathrm{Cr}, 6 \%$ Mo and balance Co was the material into which nitrogen was implanted. The specimens had a disc-like geometry with a diameter of $3 \mathrm{~cm}$ and a thickness of $0.3 \mathrm{~cm}$. Before $\mathrm{N}$ implantation, all the specimens were polished to mirror-like quality with a mean surface roughness of about $3 \mathrm{~nm}$ based on AFM.

\section{Nitrogen implantation}

$\mathrm{N}$ ion implantation was carried out with a relatively simple, broad beam, ultrahigh current density implanter. The $\mathrm{N}$ ions generated by the implantation system were not mass analyzed, but primarily consist of $\mathrm{N}_{2}^{+}(\sim 70 \%)$ and $\mathrm{N}^{+}$ $(\sim 30 \%)$. The polished CoCrMo alloy samples were ion implanted with $60 \mathrm{keV} \mathrm{N}$ ions to a high dose of $1.9 \times 10^{18}$ $\mathrm{N} / \mathrm{cm}^{2}$ at substrate temperatures of 200 and $400^{\circ} \mathrm{C}$. The $\mathrm{N}$ implantation conditions for the specimens of this study are summarized in Table I. The $\mathrm{N}$ implantation duration was $30 \mathrm{~min}$. A constant processing temperature for a given specimen was assured mainly by control of the ion beam. ${ }^{10}$

TABLE I

Nitrogen (N) Ion Implantation Conditions ${ }^{a}$

\begin{tabular}{cclr}
\hline $\begin{array}{c}\text { Temperature } \\
\left({ }^{\circ} \mathrm{C}\right)\end{array}$ & $\begin{array}{c}L_{\text {SEM }} \\
(\mathrm{nm})\end{array}$ & \multicolumn{1}{c}{$\begin{array}{c}\text { N Implanted } \\
\text { Layer Phases }\end{array}$} & $\begin{array}{c}\mathrm{Ra} \\
(\mathrm{nm})\end{array}$ \\
\hline $\begin{array}{c}\text { As-polished } \\
\text { substrate }\end{array}$ & & $\gamma-(\mathrm{Co}, \mathrm{CrMo}), \varepsilon-(\mathrm{Co}, \mathrm{Cr}, \mathrm{Mo})$ & 3.0 \\
200 & 185 & $(\mathrm{Co}, \mathrm{Cr}, \mathrm{Mo}){ }_{2}+{ }_{x} \mathrm{~N}$ nitride & 12.0 \\
400 & 450 & $\gamma_{\mathrm{N}},(\mathrm{Co}, \mathrm{Cr}, \mathrm{Mo}){ }_{2}+{ }_{x} \mathrm{~N}$ nitride & 8.0 \\
\hline
\end{tabular}

${ }^{\mathrm{a}}$ The polished CoCrMo alloy specimens were ion implanted with $60 \mathrm{keV} \mathrm{N}$ ions to a high dose of $1.9 \times 10^{18} \mathrm{~N} / \mathrm{cm}^{2}$.

Mean roughness Ra was measured by AFM for both untreated (polished) and $\mathrm{N}$ implanted CoCrMo surfaces.

\section{Characterization techniques}

Near-surface $\mathrm{N}$ implanted layer phases, implanted layer thickness, and implanted layer surface roughness were analyzed by XRD, SEM, and AFM. XRD was done in both the symmetric $\theta / 2 \theta$ and grazing-incidence (GIXRD) modes using a Philips X'pert XRD system in a step-scanning mode with $\mathrm{Cu}-\mathrm{K} \alpha$ radiation. $\theta / 2 \theta$ scan range for the samples investigated here was from $30^{\circ}$ to $90^{\circ}$. GIXRD was carried out at the incident angle of $w=1$ degree. The effective depth, which is $\sim \sin \omega / \mu$ (where $\mu$ is the linear mass absorption coefficient and is estimated to be $2540 \mathrm{~cm}^{-1}$ for CoCrMo alloy used in this research), probed by $\mathrm{Cu}-\mathrm{K} \alpha$ $\mathrm{X}$-ray beams at this incident angle is about $68 \mathrm{~nm} .{ }^{11}$ In the $\theta / 2 \theta$ XRD geometry, the effective depths probed by $\mathrm{Cu}-\mathrm{K} \alpha$ $\mathrm{X}$-ray beams are estimated to be 0.51 and $1.50 \mu \mathrm{m}$ for $2 \theta$ scan angles between $30^{\circ}$ and $100^{\circ} .{ }^{12}$ Cross-sectional SEM was done for measuring the $\mathrm{N}$ implanted layer thicknesses. Before the SEM analysis, specimens were polished, and etched electrolytically for $30 \mathrm{~s}$. The type of chemical etchant was a mixture of $\mathrm{HCl}(5 \mathrm{~mL})$ and $\mathrm{H}_{2} \mathrm{O}_{2}(100 \mathrm{~mL})$. The surface roughness of the as-polished and $\mathrm{N}$ implanted CoCrMo specimens was measured by AFM (Nanoscope IV). At least three readings were taken for each surface tested. The AFM was also used to image the surface topography of the $\mathrm{N}$ implanted as well as as-polished specimens.

\section{Bacterial adhesion test}

In this study, S. epidermidis strain YT-169a, isolated from an endotracheal tube surface of a patient hospitalized in the intensive care unit of Department of Chest Diseases, Faculty of Medicine, Ege University, Turkey, was used as a biofilm forming bacteria. The bacteria were grown in $5 \mathrm{~mL}$ tryptic soy broth (TSB) at $37^{\circ} \mathrm{C}$ for $24 \mathrm{~h}$. $\mathrm{N}$ ion implanted and aspolished specimens were sterilized by dry heat at $180^{\circ} \mathrm{C}$ for $2 \mathrm{~h}$. The sterile specimens were transferred into $100 \mathrm{~mL}$ TSB supplemented with $1 \%$ sucrose and inoculated with $200 \mu \mathrm{L}$ bacterial culture containing $1 \times 10^{9}$ colonies forming units (CFU). They were then incubated with bacteria at $37^{\circ} \mathrm{C}$ with shaking at $100 \mathrm{rpm}$ for $14 \mathrm{~h}$. At the end of incubation, the specimens were washed with sterile phosphate buffered saline (PBS) $\left(8.5 \mathrm{~g} / \mathrm{L} \mathrm{NaCl}, 0.3 \mathrm{~g} / \mathrm{L} \mathrm{KH}_{2} \mathrm{PO}_{4}, 0.6 \mathrm{~g} / \mathrm{L}\right.$ $\mathrm{Na}_{2} \mathrm{HPO}_{4}$ and $0.1 \mathrm{~g} / \mathrm{L}$ peptone, ( $\mathrm{pH}$ 7.0)) three times to remove non-adherent bacteria. They were then transferred into $25 \mathrm{~mL}$ PBS and the adherent bacteria were removed from the surfaces by scraping off by sterile cell scrapers. The removed bacteria were diluted to $10^{-3}$ and $10^{-4}$ with PBS and $100 \mu \mathrm{L}$ of the diluted bacteria were inoculated to duplicate tryptic soy agar plates. The plates were incubated at $37^{\circ} \mathrm{C}$ for $24 \mathrm{~h}$ and the number of $S$. epidermidis colonies was counted, and quantified as $\mathrm{CFU} / \mathrm{cm}^{2}$. The test for each specimen was repeated three times.

Biofilm formation by bacteria on the surfaces of the $\mathrm{N}$ implanted and as-polished materials was also visualized by SEM. For this purpose, both $\mathrm{N}$ ion implanted and as-polished specimens were incubated with bacteria in $100 \mathrm{~mL}$ TSB supplemented with $1 \%$ sucrose at $37^{\circ} \mathrm{C}$ with shaking at $100 \mathrm{rpm}$ for $24 \mathrm{~h}$. They were then washed with PBS and dried on silica gel at $37^{\circ} \mathrm{C}$ for $24 \mathrm{~h}$. 


\section{RESULTS}

\section{XRD analysis}

Figure 1 shows the XRD $(\theta / 2 \theta)$ and GIXRD results for the $\mathrm{N}$ implanted specimens at substrate temperatures of 200 and $400^{\circ} \mathrm{C}$. Included in the same figure are the results for the as-polished, untreated CoCrMo alloy sample. In Figure 1, the substrate peaks are labeled as " $\gamma$-(hkl)" for the fcc $\gamma-(\mathrm{Co}, \mathrm{Cr}, \mathrm{Mo})$ phase and " $\varepsilon$-(hkl)" for the hcp $\varepsilon-(\mathrm{Co}, \mathrm{Cr}, \mathrm{Mo})$. The XRD results for the specimen implanted at $400^{\circ} \mathrm{C}$ show additional peaks labeled as $\gamma_{\mathrm{N}}$. These new peaks are due to the formation of an interstitial phase (nitrogen atoms occupying octahedral sites in fcc lattice). The $\gamma_{N}$ phase formation is similar to that observed for $\mathrm{N}$ implantation of 304 stainless steel at $400^{\circ} \mathrm{C}$ where $\gamma_{N}$ forms from the $\gamma$ $(\mathrm{Fe}, \mathrm{Cr}, \mathrm{Ni})$ parent structure. ${ }^{13}$ Note that the parent structure of the substrate material in this study is $\gamma$ (Co,Cr,Mo). Based on Ref. 13, the $\gamma_{\mathrm{N}}$ phase was observed when the substrate temperature was held near $400^{\circ} \mathrm{C}$. At lower and higher implantation temperatures the $\gamma_{\mathrm{N}}$ is not produced. Higher implantation temperatures $\left(\geqslant 450^{\circ} \mathrm{C}\right)$ lead to $\mathrm{CrN}$, while lower implantation

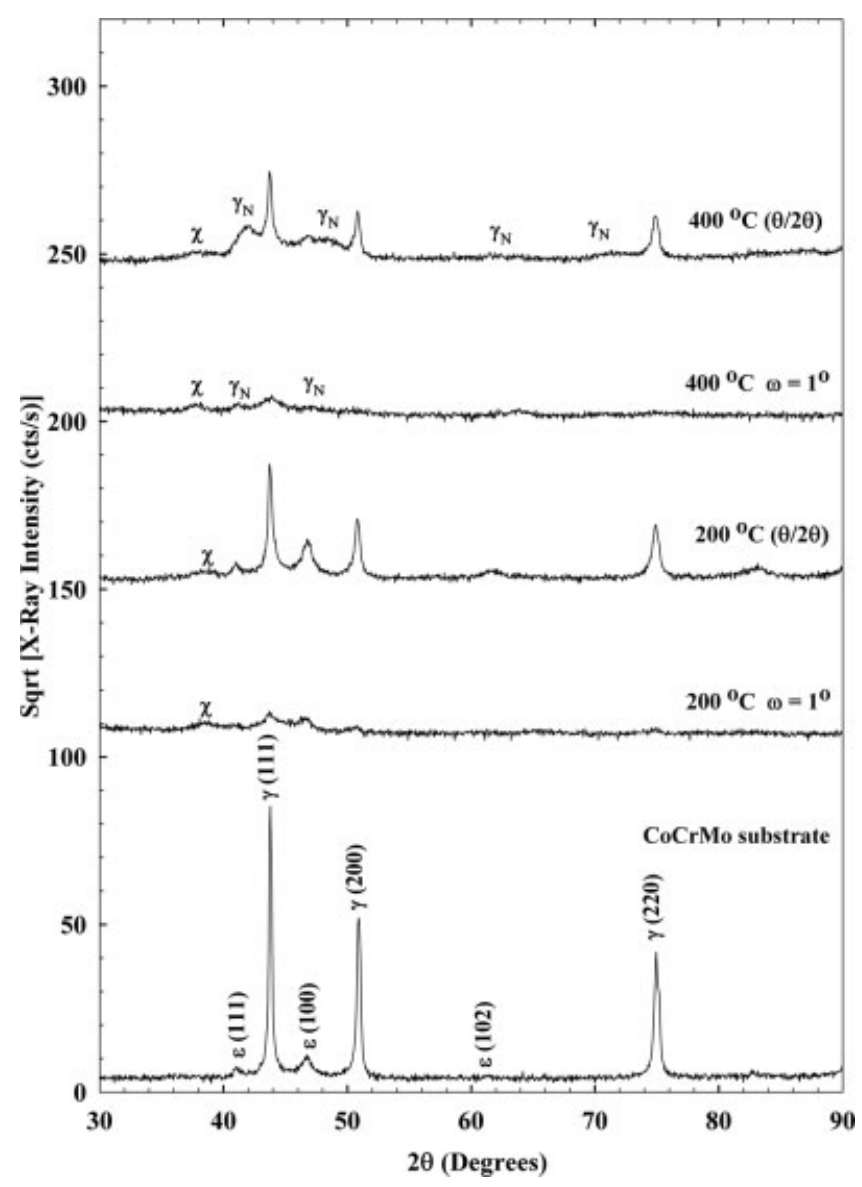

Figure 1. XRD and GIXRD data for the as-polished and nitrogen implanted specimens. Note that the square-root of the intensity is plotted to reveal the weaker peaks more clearly. temperatures $\left(\sim 200-350^{\circ} \mathrm{C}\right)$ result in a hexagonal nitride phase, $\varepsilon-(\mathrm{Fe}, \mathrm{Cr}, \mathrm{Ni})_{2}+{ }_{x} \mathrm{~N} .{ }^{13}$

The XRD results for the specimen implanted at $200^{\circ} \mathrm{C}$ show a peak labeled " $\chi$ " for the $(\mathrm{Co}, \mathrm{Cr}, \mathrm{Mo})_{2+{ }_{x} \mathrm{~N}}$ phase. The XRD peaks associated with this phase are very weak (low intensity) and broad suggesting a distribution of nitrogen in a very thin implanted layer (about $100 \mathrm{~nm}$ or less based on the SEM results to be discussed later). The $(\mathrm{Co}, \mathrm{Cr}, \mathrm{Mo})_{2+x} \mathrm{~N}$ phase is referred to as the hexagonal nitride phase and is quite similar to the epsilon nitride phase $(\mathrm{Fe}, \mathrm{Cr}, \mathrm{Ni})_{2+x} \mathrm{~N}$, which forms in the surface layers of nitrogen implanted $304 \mathrm{SS}^{13}$

To reveal the $\mathrm{N}$ implanted layer phases at the near surface, GIXRD of the $\mathrm{N}$ implanted specimens was carried out. The GIXRD results at the incident angle of $\omega=1$ degree for the specimens $\mathrm{N}$ ion implanted at 200 and $400^{\circ} \mathrm{C}$ are also shown in Figure 1. The GIXRD scans indicate that the top $\mathrm{N}$ implanted layer $(\sim 70 \mathrm{~nm})$ for the specimen implanted at $200^{\circ} \mathrm{C}$ substrate temperature is mainly composed of the $(\mathrm{Co}, \mathrm{Cr}, \mathrm{Mo})_{2+\mathrm{x}} \mathrm{N}$ nitride phase. The GIXRD results also show some contribution coming from the substrate phase due to the increased penetration depth at this angle. The XRD $(\theta / 2 \theta)$ results in Figure 1 for the specimen implanted at $400^{\circ} \mathrm{C}$ also show a small peak $(\chi)$ believed to be mainly due to the $(\mathrm{Co}, \mathrm{Cr}, \mathrm{Mo})_{2+x} \mathrm{~N}$ nitride phase. As can be seen from Figure 1, this peak is revealed much more clearly at grazing incident angle geometry.

\section{SEM analysis}

Figure 2 shows the cross-sectional SEM results for the $\mathrm{N}$ implanted specimens at the implantation temperatures of 200 and $400^{\circ} \mathrm{C}$. These pictures quite clearly reveal $\mathrm{N}$ implanted layers with a relatively uniform thickness. The $\mathrm{N}$ implanted layer thickness obtained from the picture is about $150 \mathrm{~nm}$ for the sample implanted at $200^{\circ} \mathrm{C}$. The SEM photos were taken sequentially over a span of several grains to look for $\mathrm{N}$ implanted layer thickness variations. So, based on several SEM photos, the average $\mathrm{N}$ implanted layer thickness for the $200^{\circ} \mathrm{C}$ sample is $185 \mathrm{~nm}$. The SEM picture for the specimen implanted at $400^{\circ} \mathrm{C}$ quite clearly reveal the extremely uniform nature of the $\mathrm{N}$ implanted layer, which is mainly composed of the $\gamma_{N}$ phase based on the XRD results. The $\gamma_{N}$ layer thickness found from the SEM picture in Figure 2 is about $400 \mathrm{~nm}$, while the average $\gamma_{N}$ layer thickness is estimated to be $450 \mathrm{~nm}$. The average layer thicknesses for the $\mathrm{N}$ implanted specimens determined by the cross-sectional SEM analysis are given in Table I.

\section{AFM analysis}

In Figures 3 and 4, 3D AFM images of specimens' surfaces before and after $\mathrm{N}$ ion implantation are com- 

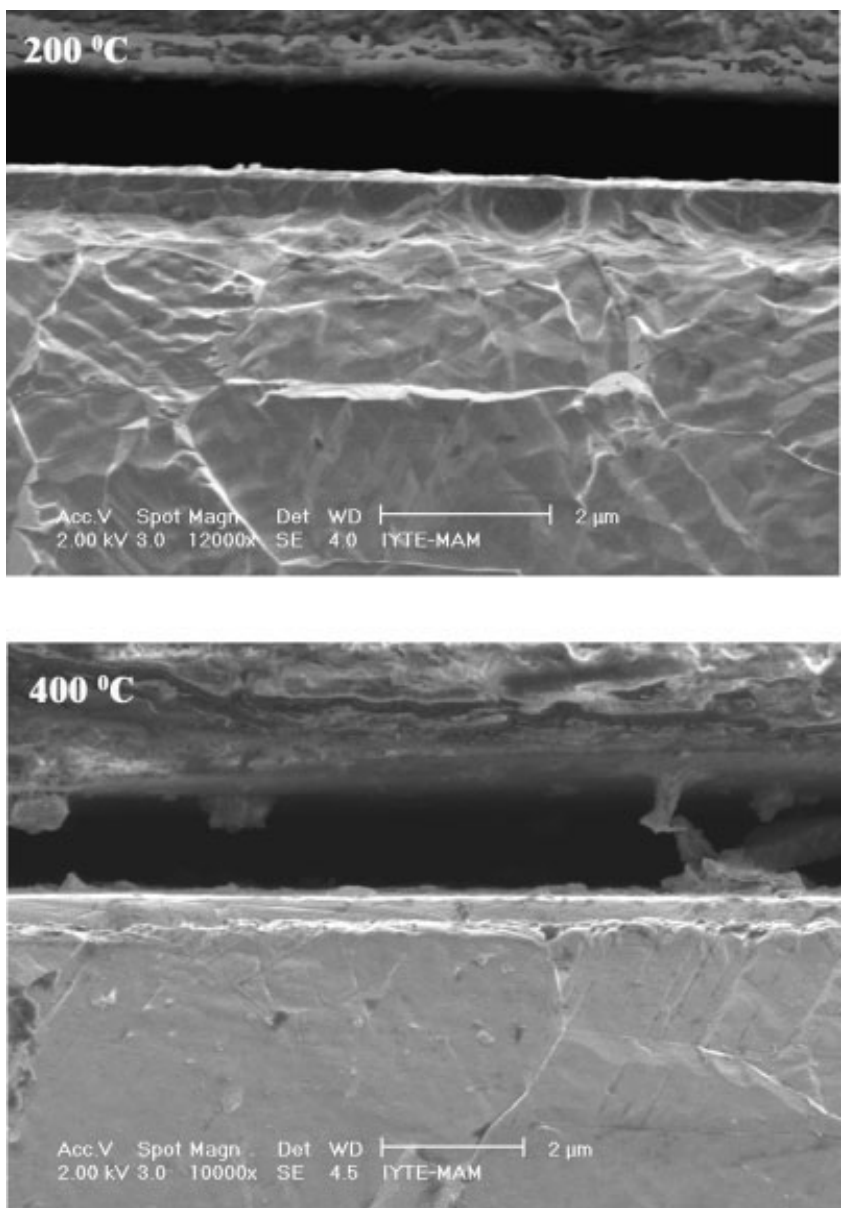

Figure 2. Cross-sectional SEM images for the specimens nitrogen implanted at substrate temperatures of 200 and $400^{\circ} \mathrm{C}$.

pared. These figures clearly demonstrate different surface topography of samples in 3D view. The AFM image of the as-polished surface shows that it is

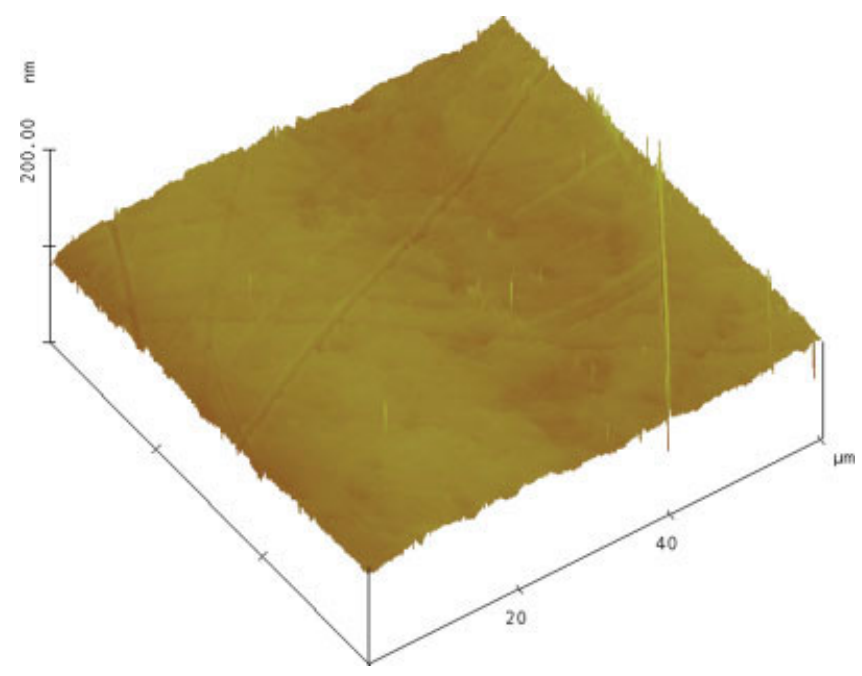

Figure 3. Three-dimensional AFM image of the as-polished (unimplanted) CoCrMo substrate alloy surface. [Color figure can be viewed in the online issue, which is available at www.interscience.wiley.com.]
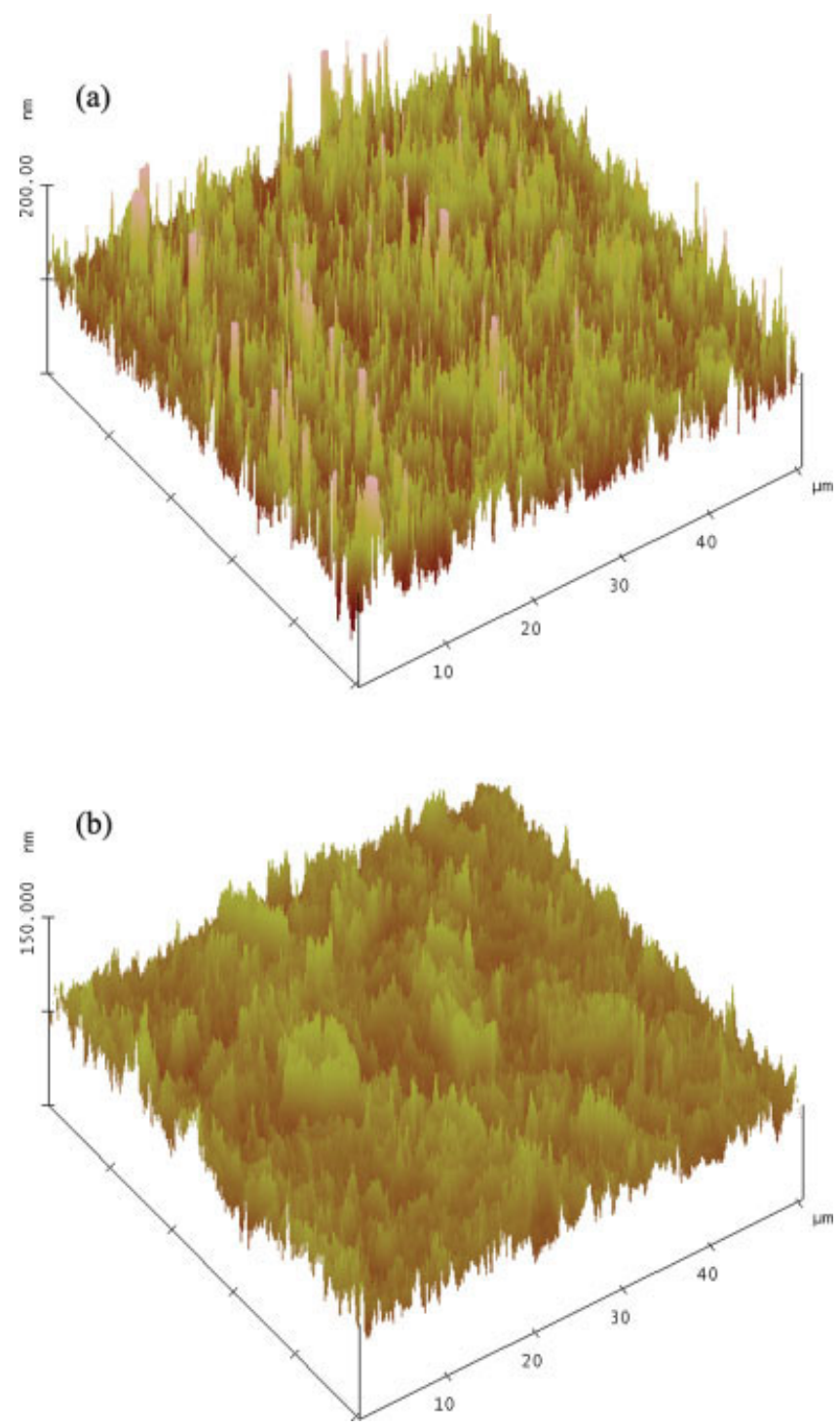

Figure 4. Three-dimensional AFM images of the $\mathrm{N}$ implanted specimens at substrate temperatures of (a) $200^{\circ} \mathrm{C}$ and (b) $400^{\circ} \mathrm{C}$. [Color figure can be viewed in the online issue, which is available at www.interscience.wiley.com.]

rather smooth and featureless. The average roughness (Ra) value for the as-polished surface is found to be $3 \mathrm{~nm}$. The 3D AFM images in Figure 4 clearly indicate that surface roughness is strongly increased by $\mathrm{N}$ ion implantation. The Ra values calculated from these images are about 12 and $8 \mathrm{~nm}$ for the specimens implanted at 200 and $400^{\circ} \mathrm{C}$, respectively. The roughness values for the as-polished as well as $\mathrm{N}$ implanted specimens can also be found in Table I.

\section{Bacterial adhesion test}

The number of attached bacteria to the as-polished (unimplanted) and $\mathrm{N}$ implanted surfaces were quantified by bacterial adhesion test. It is found that the mean number of bacteria on the surfaces of $\mathrm{N}$ 
implanted specimens at 200 and $400^{\circ} \mathrm{C}$ specimens were $191 \times 10^{6} \mathrm{CFU} / \mathrm{cm}^{2}$ and $70 \times 10^{6} \mathrm{CFU} / \mathrm{cm}^{2}$, respectively. The number of bacteria on the as-polished CoCrMo alloy surface is found to be $3 \times 10^{6} \mathrm{CFU} / \mathrm{cm}^{2}$.

\section{DISCUSSION}

The bacterial adhesion test results presented above suggest that the $\mathrm{N}$ implanted layers/surfaces may not be beneficial for preventing or reducing bacterial adhesion on CoCrMo alloy surfaces or both. The results clearly indicate that $S$. epidermidis strain YT169a adhere much more efficiently to the surfaces of $\mathrm{N}$ implanted specimens. This is mainly attributed to the much rougher surfaces of the $\mathrm{N}$ implanted specimens compared to the rather smooth surface of the as-polished specimen. The test results further indicate that the bacteria adhere strongly to the surface of the specimen implanted at $200^{\circ} \mathrm{C}$ compared to that implanted at $400^{\circ} \mathrm{C}$. This is also believed to be due to the roughness differences between these two samples; as can be seen from Table I, the specimen implanted at $200^{\circ} \mathrm{C}$ has a larger surface roughness $(12 \mathrm{~nm}) \mathrm{com}-$ pared to the specimen implanted at $400^{\circ} \mathrm{C}(8 \mathrm{~nm})$.

The SEM images in Figure 5 show biofilm formation by S. epidermidis strain YT-169a on the surfaces of the $\mathrm{N}$ implanted specimens. These images clearly indicate the cell-to-cell interactions by slime formation by the bacteria and the physicochemical interactions between the bacteria and the surface of the $\mathrm{N}$ implanted material. It is known that these cellular and physicochemical interactions play a significant role in biofilm formation. ${ }^{2}$

There are varying opinions as to the effect of surface characteristics on bacterial adhesion. While a number of researchers report a positive correlation between adhesion and increased surface roughness, others report no correlation between surface roughness and the ability of bacteria to attach. ${ }^{14,15}$ A recent research study investigating adhesion of thermo-resistant streptococci on 316L and 304L stainless steels found that adhesion could not be related to increases in surface roughness but surface topography around a critical size close to the diameter of the bacterial cells may entrap bacteria. ${ }^{16}$ Another research study mentions that electropolished surfaces are more resistant to bacterial adhesion than are those with a higher surface roughness. ${ }^{17}$

The present study finds no correlation (positive or negative) between bacterial adhesion and the $\mathrm{N}$ implanted layer phases. A detailed analysis of the nature of the $\mathrm{N}$ implanted layer phases as well as their surface characteristics such as hydrophobicity, electrical charge, and passive film seems to be necessary. For the as-polished CoCrMo alloy, its native oxide layer
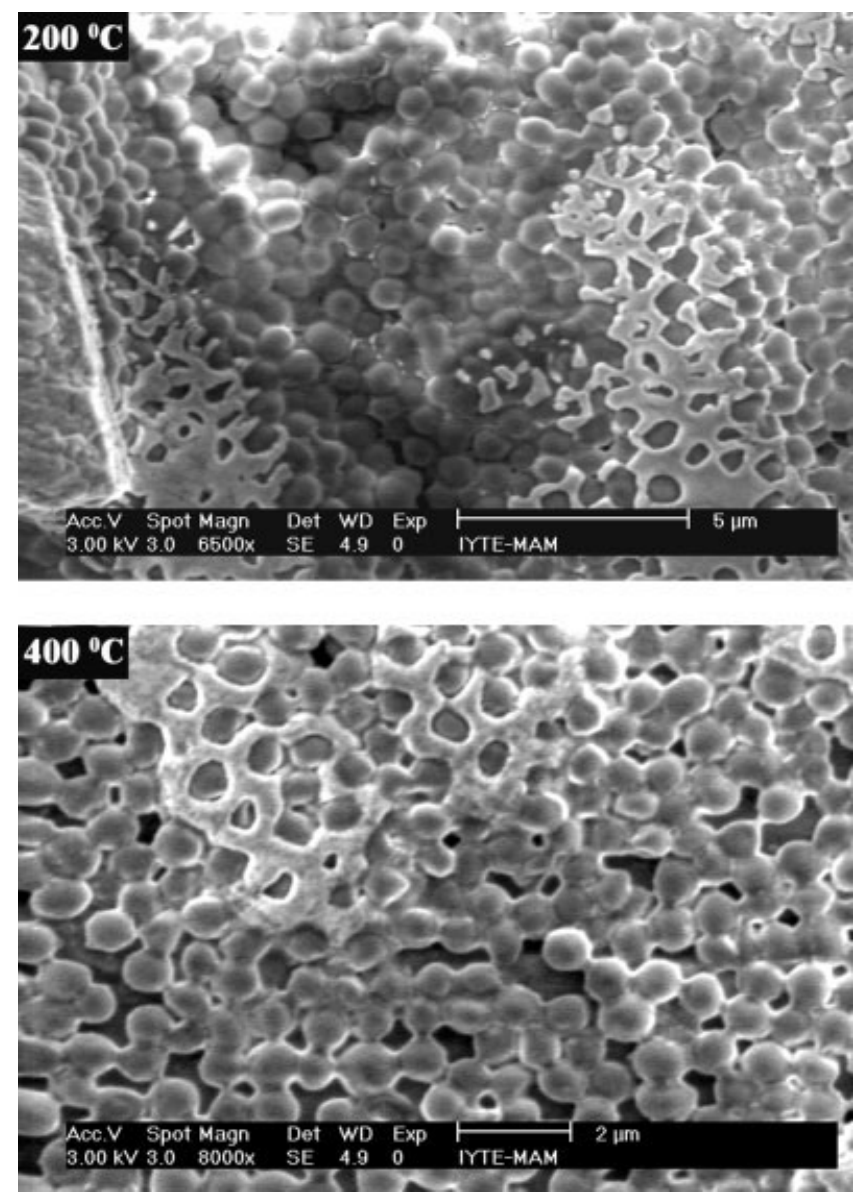

Figure 5. SEM images showing bacterial adhesion and biofilm formation on the nitrogen implanted specimens at 200 and $400^{\circ} \mathrm{C}$.

(predominantly composed of $\mathrm{Cr}_{2} \mathrm{O}_{3}$ with some minor contributions from Co and Mo oxides) might also play a role in attracting less bacteria compared to the $\mathrm{N}$ implanted surfaces. However, the study in Ref. 16 found that the native oxide layer on stainless steel enhances bacterial adhesion compared to the surface whose oxide layer was damaged or removed by an acid treatment. There is no conclusive evidence on the formation of oxide layer(s) on the $\mathrm{N}$ implanted surfaces investigated in this research study. A thin oxide layer would probably form on the surfaces of the $\mathrm{N}$ implanted specimens in air after the implantation. It would be important to investigate the physiochemical characteristics of the $\mathrm{N}$ implanted as well as as-polished surfaces since it is believed to be an important factor governing bacterial adhesion. ${ }^{2,16}$

\section{CONCLUSIONS}

In this study, the adhesion of biofilm forming ability of S. epidermidis strain YT-169a on N implanted 
CoCrMo surfaces was investigated. The bacterial adhesion test showed that S. epidermidis strain YT-169a adhere preferentially to the $\mathrm{N}$ implanted surfaces compared to the as-polished substrate alloy material and more bacteria adhered to the specimen implanted at $200^{\circ} \mathrm{C}$ than to the specimen implanted at $400^{\circ} \mathrm{C}$. The SEM images also indicated thick biofilm formation on the surfaces of the $\mathrm{N}$ implanted CoCrMo specimens. Stronger bacterial adhesion behavior of the $\mathrm{N}$ implanted surfaces compared to the as-polished surface was attributed mainly to the rougher surfaces associated with the $\mathrm{N}$ implanted specimens compared to the relatively smooth surface of the untreated CoCrMo alloy material. The present study finds no correlation between bacterial adhesion and the $\mathrm{N}$ implanted nearsurface crystal structures. In order to establish a correlation, a much more detailed analysis of the $\mathrm{N}$ implanted surfaces is required.

The authors are grateful to Hipokrat A.S. for supplying medical grade CoCrMo alloys and to Prof. Paul Wilbur of Colorado State University, CO, USA, for carrying out the N ion implantation on CoCrMo substrates.

\section{References}

1. Rupp ME, Archer GL. Coagulase-negative staphylococci: Pathogens associated with medical progress. Clin Infect Dis 1994;19: 231-243.

2. An YH, Friedmen RJ. Consive review of mechanisms of bacterial adhesion to biomaterial surfaces. J Biomed Mater Res B: Appl Biomater 1998;43:338-348.

3. An YH, Friedmen RJ. Laboratory methods for studies of bacterial adhesion. J Microbiol Methods 1997;30:141-152.

4. Arciola CR, Campoccia D, Gamberini S, Donati ME, Pirini V, Visai L, Speziale P, Montanaro L. Antibiotic resistance in exopolysaccharide-forming Staphylococcus epidermidis clinical isolates from orthopaedic implant infections. Biomaterials 2005;26:6530-6535.

5. Klueh U, Wagner V, Kelly S, Johnson A, Bryers JD. Efficacy of silver-coated fabric to prevent bacterial colonization and subsequent device-based biofilm formation. J Biomed Mater Res 2000;53:621-631.

6. Hashimoto H. Evaluation of the anti-biofilm effect of a new antibacterial silver citrate/lecithin coating in an in-vitro experimental system using a modified robins device. J Japan Assoc Infect Dis 2001;75:678-685.

7. Smidt FA, Hubler GK. Recent advances in ion beam modification of metals. Nucl Instrum Methods B 1993;80/81:207-216.

8. Cui FZ, Luo ZS. Biomaterials modification by ion-beam processing. Surf Coat Technol 1999;112:278-285.

9. Mandl S, Rauschenbach B. Improving the biocompatibility of medical implants with plasma immersion ion implantation. Surf and Coat Technol 2002;156:276-283.

10. Wilbur PJ, Daniels LO. The development and application of an ion implanter based on ion thruster technology. Vacuum 1986; 36:5-9.

11. Cullity BD. Elements of X-ray Diffraction. Addison Wesley, Massachusetts; 1978. 138 p.

12. Ozturk O, Turkan U, Eroglu AE. Metal ion release from nitrogen ion implanted CoCrMo orthopedic implant material. Surf Coat and Technol 2006;200:5687-5697.

13. Ozturk O, Williamson DL. Phase and composition depth distribution analysis of low energy, high flux $\mathrm{N}$ implanted stainless steel. J Appl Phys 1995;77:3839-3850.

14. Wirtanen G, Ahola H, Mattila-Sandholm T. Evaluation of cleaning procedures in elimination of biofilm from stainless steel surfaces in open process equipment. Trans Int Chem Eng 1995;73:1-9.

15. Vanhaecke E, Remon JP, Moors M, Raes F. Kinetics of Pseudomonas aeruginosa adhesion to 304 and 316-L stainless steel: Role of cell surface hydrophobicity. Appl Environ Microbiol 1990;56:788-795.

16. Flint SH, Brooks JD, Bremer PJ. Properties of the stainless steel substrate, influencing the adhesion of thermo-resistant streptococci. J Food Eng 2000;43:235-242.

17. Zoltai PT, Zottola EA, McKay LL. Scanning electron microscopy of microbial attachment to milk contact surfaces. J Food Prot 1981;44:204-208. 